\title{
Students' Attitudes Towards the Use of Google Forms as an Online Grammar Assessment Tool
}

\author{
Syaiful Jazil \\ Education and Teachers Training Faculty \\ UIN Sunan Ampel \\ Surabaya, Indonesia \\ syaifuljazil@uinsby.ac.id \\ Laras Ayuningtyas Manggiasih \\ Education and Teachers Training Faculty \\ UIN Sunan Ampel \\ Surabaya, Indonesia \\ larasuinsa@gmail.com
}

\author{
Kurnia Firdaus \\ Education and Teachers Training Faculty \\ UIN Sunan Ampel \\ Surabaya, Indonesia \\ niafirdaus55@gmail.com \\ Puri Mega Chayani \\ Education and Teachers Training Faculty \\ UIN Sunan Ampel \\ Surabaya, Indonesia \\ purimegachayani@gmail.com
}

\author{
Nely Rahmatika \\ MTs. Masyhudiyah Giri \\ Gresik, Indonesia \\ bolanely@687@gmail.com
}

\begin{abstract}
The use of online assessment tool has been a debatable issue among teachers. However, it can be easy for teachers to assess students' understanding. They could use an online assessment tool such as google form to examine grammar understanding. This study was aimed to find out students' attitudes of junior high school students using google forms in their assessment. This research used a qualitative design to take the data. This research was conducted at MTs Masyhudiyah Gresik with 25 students as the participant. The techniques of data collection were testand interview. The finding of this research will show how students behave towards the use of google form as an online assessment.
\end{abstract}

Keywords: students' attitude, grammar, online assessment

\section{INTRODUCTION}

Digital learning has been taking its place in the education field since technology is accessible and easy to reach. Students who use social media and apply it in their learning process increased rapidly. It can be defined that digital learning is effective to strengthen students learning experience. It is realized that the future learning process is digital, and it impacts not only the learning procedure but also the learners and the teachers as a whole. Technology expansion has influenced the system of education due to some positive effects such as (a) Technology can improve test scores, grades and overall student learning (Bain \& Ross, 2000)(b) increased knowledge and opportunity (Tienken and Wilson, 2007) (c) motivating students in learning process (Spires, 2008).

It is recognizable that technology usage brings advantages in some aspects. The positive effect of technology in education also can be seen in constructing assessment, like what is stated by Spires, 2008 that most students use technology in the learning process in term of listening to the teachers' explanation and doing the worksheet. Regarding this statement, teachers attempt to take the benefit of technology as a media in teaching. They start to design their assessment online. In applying an online assessment, teachers choose to use LMS (learning management system). LMS is an effective tool for teachers to design an online-based assessment.

In some cases, LMS can be a beneficial facilitator that helps the teacher to produce students' task. Nowadays, google form becomes the most chosen option for teachers to design an online task for students since it helps the teacher to develop quizzes and surveys. Google form can be used for a variety of productivity tasks. Some reasons to use google form for students' task are stated regarding its gain, such as providing various types of question, applying the validation option, watching students' progress, etc. This feature allows the teacher to design such various types of test. This positive effect support teacher to design the test based on their need. In designing a grammar test, the teacher may have some choices to construct good test items before they give them to the students. Creating a grammar test can be applied in many ways. It is possible that teachers design grammar test in multiple choices questions or even essay; those can be applied through a google form.

Using google form to design an online assessment is a new upswing which is expected to represent a new learning method in an enchanted way because it is effective and flexible. This study is focusing on exploring how students behave through the use of google form as an online assessment since it is important to be known by the teacher. Likewhat is stated by Selim, 2007:396-413positive attitudes of students' and behaviours regarding online learning are important and necessary for the acceptance and adoption of online learning. Attitude defines as the way of one's thinking and behaves toward a certain term like a person, a thing, or an event sometimes. Eshreteh and Siaj 
(2017) define attitudes as the way one thinks or behaves, a complex mental state involving feelings, values, and dispositions to act in certain ways. In this case, it is possible that while exploring students attitude, students will show positive or negative views towards the use of Google form as an online assessment.

Students nowadays have been the central focus in teaching and learning process related to the learning strategies, time of teaching, method of teaching, also the assessment methodologies. One strategy to promote a student-centred educational model is online assessment; which can be the main component in effective learning. This idea is in line with Gikandi (2011) idea which stated that "teaching and learning processes need to be assessmentcentred to provide learners with opportunities to demonstrate their skills development and receive support to enhance their learning". Following Osuji (2012) asserts that e-assessment could be considered as the use of technology to facilitate the entire process of assessment, starting from designing and delivering the assignments to marking either by computers or human-assisted by digital tools, reporting, scoring the results and/or making the statistical analysis. It will enable the teachers to handle a large number of classes because tests and grading are done automatically. Online examination has several terms, including online test, eassessment, e-examination, online assessment, web-based assessment, and a computer-based assessment. All of them have the same aspects of using technology and the internet in their application.

This study will use Google form as an online assessment tool, considering the result can be recorded as soon as the students finish the test. As stated by Agrawal \& Maurya (2016) that "the results generated from the online survey method (Google forms) are assured as they are generated in the form of diagrams which cannot be edited. The excel sheet that contains the respondent's data can be modified, but those changes don't reflect in the result diagrams. This makes the resultant diagrams more assured and only shows the actual data filled by the respondents". This research will use a Google form to assess students' ability in English grammar, considering it deals with four skills which are listening, speaking, writing, and reading. As Debata (2013) stated that a person could not learn a foreign language correctly only through an unconscious-assimilation process and grammar is a sure ground of reference when linguistic habits fail us. So, grammar is required for the students in mastering four English skills.

This study is concerned with students' attitudes toward online grammar assessment.Eshreteh and Siaj (2017) define attitudes as the way one thinks or behaves, a complex mental state involving feelings, values, and dispositions to act in certain ways. Attitude affects a student's ability to do the test. Moreover, attitudes can represent positive or negative views towards a person, a thing, or an event sometimes. Wang (2006) pointed out the students' positive attitudes in online assessment. First, the students enjoy taking the online assessment anytime as long as it falls within the deadline. Second, the students feel free to have several attempts at the test until they can achieve the minimum score. Third, it can reduce students' anxiety in waiting for feedback. Karim and Shukur (2016) also stated the students' negative attitude in having online assessment which is students feel anxiety as it has the time limit to do the test, students are worried since there is no time to open the book or ask someone else, and students' willingness in terms of the unstable internet connection.

\section{METHOD}

The method that is employed in this study is a qualitative research method. This research was conducted at MTs Masyhudiyah Gresik on $31^{\text {st }}$ July 2019 until $30^{\text {th }}$ September 2019 to coincide with the implementation of Praktik Pengalaman Lapangan (PPL) II and Praktik Manajemen Pendidikan Islam (PMPI). Subjects in this grammar material are students of class VIII-B in MTs Masyhudiyah Gresik, with 25 students as a participant. In this study, the data were tested by interviewing to find out the attitudes of students regarding the use of Google Forms as an online tool for grammar assessment after doing several grammar questions that had been prepared on Google Forms. The data collection technique was interviewing 25 students to determine student attitudes.

\section{FINDINGS AND DISCUSSION}

The use of Google form has never been applied in this school, considering the limitation of ICT. The teachers noted that the school has computer laboratory, but it can't be used optimally since the laboratory is owned by all institution in Tarbiyatul Athfal Masyhudiyah (Islamic primary school, junior and senior high school. Besides that, the computer lesson is only given to ninth-grade students. When the teachers were asked why they don't apply Google form in the students' mobile phone, the teachers said that the students are prohibited from bringing their mobile phone at school. So that it is a little bit difficult to apply online assessment at this school. Due to this research, it can be their first experience in using Google form for grammar task.

The results of this study showed that the students have positive and negative attitudes towards the use of Google forms in online grammar assessment. 23 to 25 students pointed out positive attitudes in using Google form as an online assessment, and the rest confirmed negative attitudes in the use of Google forms. An interview was done after the students doing their test. There were random students requested to join the interview to find what the problems they might encounter during the test and what were their opinions about the application. Most of the students claimed their positive attitudes, such as more challenging in having an online assessment, more effective to apply, having immediate feedback after doing the test, having several attempts to achieve a minimum score. The students firmly mentioned their positive attitudes about the use of Google form in online grammar assessment.

\section{A. More Challenging}

Online learning platforms present a variety of opportunities in assessing students' learning. These opportunities involve both teachers and students, yet in this study only focuses on the students. In an experimental study, Hwang and Chang (2011) found that formative assessmentbased mobile learning approach has a meaningful effect on student learning interest as well as their learning achievement. Another experimental study revealed that students in the formative assessment test group generally learned more and demonstrated more positive attitudes towards learning materials and future learning (Lawton et al., 2012). It is proved by one of the interviewees explained that online assessment is more challenging since the students can't rely on someone else. 
"I think doing online test challenges myself to do the test properly as I should answers all the questions by myself because of the limitation of time. All of my friends are concerned with their own test, so there is no chance to ask others."

Besides that, another student also claimed that using online assessment is more challenging since Google form provides a direct result with the discussion. The direct result should be a good term in using Google form because it allows students to learn directly.

"I actually feel nervous when the result is displayed. So I think Google form is challenging for me."

\section{B. More Effective}

The interviewee mentioned the effective time to do the test, as stated below,

"Using Google form as an online assessment is quite fun due to the flexible and effective time. We don't need to do the test in a common duration which is 60 minutes or 90 minutes since the test requires us to do faster."

Another interviewee also stated that by using online assessment will minimize the use of time regarding the students need to write more in a paper-based test.

"I prefer an online test than paper-based test as I don't need to use my pencil, pen, or the correction pen. Using those kinds of stuff are really wasting time instead of just clicking."

\section{Direct Feedback}

One of the interviewees emphasised that Google form in online assessment tool has a positive side which affects students' readiness in doing the test. This finding is supported by Emrah (2015), which stated that sophisticated ICT had been a good offer for students' access. It is essential to pay attention to technological development in the evaluation as it has integrated with education. It defines that by using technology, the test report can be done faster, and it will be more economical.McLaughlin \& Yan (2017) also concluded that formative feedback in the form of online assessment has the potential to encourage student engagement, bolster student enthusiasm to learn, and lead to improved academic achievement.

"I don't need to wait for a long time in order to get the result, because it can immediately come up after I have finished the test. Also, I can have an evaluation in which I get the wrong answers."

However, direct feedback can be a negative effect since it causes nervous for several students while in the usual task, it takes a lot of time to be corrected by the teacher.

"I actually feel nervous when the result is displayed. So I think Google form is challenging for me."

\section{Several Attempts}

Wang (2006) pointed out one of the students' positive attitudes in online assessment is the students feel free to have several attempts at the test until they can achieve the minimum score. One of the interviewees also stated that Google form enables the students to get several attempts to achieve the target score as long as the teacher permits the students to do so.

"I should have got the score that I really want as I can do the test for several times if I am permitted."

However, there is one student claimed that they don't prefer to online assessment due to the limitation of ICT. The student mentioned that the use of online assessment makes them feel awkward to use it as stated below
"I rarely use a computer nor a laptop. It's because I don't have it at home. My parents can't buy it for me. There is a computer laboratory at school, but we rarely use it too. So, it's a little bit awkward when I moved the arrow through that box (track-pad). It's easier for me to move the arrow using the mouse."

This finding has been in line with Further, Ghasemi\& Hashemi (2011) who asserted a list of reasons why ICT is not used in classrooms. According to him, the limitations of using ICT as an educational tool are financial barriers, availability of computer hardware and software, lack of technical and theoretical knowledge and reluctance to accept the technology.

Another student also mentioned the contrary attitudes in using Google form as an online assessment. The students claimed that there is no significant improvement in learning either by using online or by using paper as stated below,

"It's a new thing to do a test using Google form. It's the same with doing a grammar test in a paper; the difference is that we did it with different media, with technology which is more modern than paper."

"None of them consider that they have proved are volution in the field of education, in part because computers are used to work in the same way as in traditional teaching. Neither are they in favour of excessive use of computers in the language classroom because they consider that they interrupt their development and their usual dynamics" (Malagón\&Pérez, 2017)

\section{CONCLUSION}

The growth of ICT has been integrated into education. A various online examination can be done using ICT, including Google form test. The students give several behaviour in both positive and negative attitudes in using Google form as an online assessment. Those behaviour can be the reflection on making better students' measurement. The research intention of this study was as an online assessment example of using technology for the students and the action after applying it. For further research, it can be using Google form with better time limitation. Also, using other platforms are recommended to do in creating an online test for students.

\section{REFERENCES}

[1] Agrawal, A., Aurangzeb, M., \&Maurya, L. S. (2016). A Current Study on the Limitations of Agile Methods in Industry Using Secure Google Forms. Procedia - Procedia Computer Science, 78(December 2015), 291-297. https://doi.org/10.1016/i.procs.2016.02.056

[2] Bhuasiri, W., Xaymoungkhoun, O., Zo, H., Rho, J.J. \& Ciganek, A.P (2012). Critical Success Factors for E-Learning in Developing Countries: A Comparative Analysis between ICT Experts and Faculty. Computers \& Education, 58(2), 843-855

[3] Chang, C.-W. (2005). Oral Language Assessment: Teachers Practices and Beliefs in Taiwan Collegiate EFL Classrooms with Special Reference to Nightingale University. PHD, University of Exeter, Exeter

[4] Chu, R. J., \& Chu, A. Z. (2010). Multi-level analysis of peer support, internet selfefficacy and e-learning outcomes-the contextual effects of collectivism and group potency. Computers \& Education, 55(1), 145-154

[5] Debata, Pradeep Kumar. (2013). The Importance of Grammar in English Language Teaching - A Reassessment. Language in India. Retrieved from: www.languageinindia.com ISSN 1930-2940 Vol. 13:5 May 2013

[6] Eshreteh, Mahmood K.M \&Siaj, Azhar Hisham. Attitudes of English-Major Students and Teachers towards Using Blended Learning in the English Department at Hebron University. International Journal of Research in English Education. Hebron University, Palestine. 
among Biology-major university students in Taiwan. Journal of Science Education and Technology, 21(6):796-807. https://doi.org/10.1007/s10956-012-9367-y

[15] Lawton, D., Vye, N., Bransford, J., Sanders, E., Richey, M., French D., \& Stephens, R. (2012). Online learning based on essential concepts and formative assessment. Journal of Engineering Education, 101(2), 244-287.

[16] Malagón, C. G., \& Pérez, M. L. (2017). ICT in the English classroom. Qualitative analysis of the attitudes of teachers of English towards its implementation in Secondary Schools. Procedia

[17] McLaughlin, T., \& Yan, Z. (2017). Diverse delivery methods and strong psychological benefits: A review of online formative assessment. Journal of Computer Assisted Learning, 33, 562-574. http://dx.doi.org/10.1111/jcal.12200

[18] Osuji U (2012) The Use Of E-Assessments in The Nigerian Higher education System. Turkish Online J Distance Educ 13(4):140-152

[19] Selim, H. M. (2007). Critical success factors for online learning acceptance: Confirmatory factor models. Computers and Education, 49, 396-413

[20] Wang, K. H., Wang, T., Wang, W.-L., \& Huang, S. (2006). Learning styles and formative assessment strategy: enhancing student achievement in Web-based learning. Journal of Computer Assisted Learning, 22(3), 207-217. https://doi.org/10.1111/j.1365$2729.2006 .00166 \mathrm{x}$
[14] Lin YC, Liang JC \& Tsai CC 2012. The relationships between epistemic beliefs in Biology and approaches to learning Biology 